\title{
Development of agar diffusion method for dosage of gramicidin
}

\author{
Ana Gabriela Reis Solano ${ }^{1,2, *}$, Larissa de Melo Campos Sousa Pereira ${ }^{2}$, Míriam de Fátima Vianna \\ Leonel$^{2}$, Elzíria de Aguiar Nunan ${ }^{2}$
}

${ }^{1}$ Dona Lindu Mid-West Campus, Federal University of São João Del Rei, ${ }^{2}$ Department of pharmaceutical products, Faculty of Pharmacy, Federal University of Minas Gerais

\begin{abstract}
Gramicidin, an antimicrobial peptide active against Gram positive bacteria, is commonly used in pharmaceutical preparations for topical use. Considering that only the turbidimetric method has been described in the literature, the present study sought to develop and validate an agar diffusion method for the dosage of gramicidin. The method was developed and validated using the Kocuria rhizophila ATCC 9341 as a test microorganism. Two designs were used: a 3x3 parallel-line model, and a 5x1 standard curve. The validation demonstrated that the method follows the linear model $\left(\mathrm{r}^{2}=0.994\right)$, presenting a significant regression between the zone diameter of growth inhibition and the logarithm of the concentration within the range of 5 to $25.3 \mu \mathrm{g} / \mathrm{mL}$. The results obtained for both designs were precise, having a relative standard deviation (R.S.D.) for intra-day precision of 0.81 for the $3 \times 3$ assay and 1.90 for the $5 \times 1$ assay. For the inter-day precision, the R.S.D. was 1.35 for the $3 \times 3$ and 2.64 for the $5 \times 1$. The accuracy was verified and results confirmed to be accurate, having a tolerance interval of $95 \%$, which lay within permitted limits and appropriate trueness. In addition, the method was considered selective, with limit of detection and upper and lower limits of quantification of $2.00,5.00$ and $25.3 \mu \mathrm{g} / \mathrm{mL}$, respectively. No difference in precision between the designs used in the agar diffusion method was evident $(p>0.05)$. The method proved to be appropriate for the microbiological dosage of the raw material gramicidin.
\end{abstract}

Uniterms: Gramicidin/microbiological assay. Microbiological assay/method validation. Agar diffusion. Cylinder-plate.

A gramicidina, um peptídeo antimicrobiano ativo contra bactérias Gram positivo, é utilizada em preparações farmacêuticas de uso tópico. Neste trabalho procurou-se desenvolver e validar outro método para o doseamento de gramicidina tendo em vista que somente o método turbidimétrico é descrito. O método de difusão em ágar foi desenvolvido e validado utilizando como microrganismo teste Kocuria rhizophila ATCC 9341. Foram utilizados dois delineamentos: retas paralelas 3x3 e curva padrão 5x1. A validação demonstrou que o método segue o modelo linear $\left(\mathrm{r}^{2}=0,994\right)$ havendo regressão significativa entre o diâmetro dos halos de inibição e o logaritmo da concentração na faixa de 5,00 a 25,3 $\mu \mathrm{g} / \mathrm{mL}$. Os resultados obtidos por ambos os delineamentos foram precisos apresentando desvio padrão relativo (DPR) para precisão intra-dia de 0,81 para ensaio $3 \times 3$ e de 1,90 para ensaio 5x1. Para a precisão interdias o DPR foi de 1,35 para $3 \times 3$ e de 2,64 para $5 \times 1$. A exatidão foi verificada e os resultados foram exatos apresentando intervalo de tolerância a $95 \%$ dentro dos limites permitidos e veracidade adequada. O método foi seletivo com limites de detecção e quantificação inferior e superior iguais a 2,00, 5,00 e $25,3 \mu \mathrm{g} / \mathrm{mL}$, respectivamente. Não foi observada diferença entre a precisão dos delineamentos empregados no método de difusão em ágar ( $>>0.05$ ). O método se mostrou adequado para a dosagem microbiológica de gramicidina matéria-prima.

Unitermos: Gramicidina/doseamento microbiológico. Doseamento microbiológico/validação de método. Difusão em Agar. Cilindros em placa.

\footnotetext{
*Correspondence: A. G. R. Solano. Universidade Federal de São João Del Rei, Campus Centro Oeste Dona Lindu. Rua Sebastião Gonçalves Coelho, 400, sala 201, bloco A, Chanadour - 35501-296 - Divinópolis - MG, Brasil. E-mail: anagabriela@ufsj.edu.br
} 


\section{INTRODUCTION}

Gramicidin is a neutral linear pentadecapeptide present in the antimicrobial mixture tyrothricin (gramicidin + tyrocidine), produced by Bacillus brevis. Isolated gramicidin acts against Gram positive bacteria, forming canals specifically for monovalent metals and ammonium cations in cell membrane, thus increasing its permeability (Koo et al., 2001).

This material is used in pharmaceutical forms for isolated topical use, or in combination with other antibiotics for the treatment of bacterial infections (Bosscha et al., 2004; Zaias et al., 1981).

Previous studies in the literature have reported on the turbidimetric method for determining the activity of the raw material gramicidin (United States Pharmacopoeia, 2008; British Pharmacopoeia, 2007). However, in practice, this method has proven to be ineffective and relatively susceptible to variations, thus leading to non-repeatable results and to the need for several repetitions.

In 1958, Vuilleumier and Anker developed the agar diffusion method to determine the potency of tyrothricin, but this method called for a long period of pre-diffusion of approximately 8 hours, yet only small zone diameters could be obtained (Vuilleumier, Anker, 1958). This method was modified by Viola and Canestrini in 1966 who, to obtain larger zone diameters, increased the pre-diffusion time even more (20 hours). These methods, used to determine the proper potency of tyrothricin, proved to be unsuitable for normal laboratory routines, considering that they demanded an extensive time period for execution and were never validated because no such procedures were required at the time. After 1966, no other information regarding the dosage of tyrothricin or gramicidin can be found.

Against this background, the present study set out to develop an agar diffusion method for determining the dosage of the raw material gramicidin and to validate it by means of parameters of selectivity, accuracy, calibration curve, precision, robustness, and detection and quantification limits (Hubert et al., 2007a,b; Rozet et al., 2007a; Brasil, 2003; FDA, 2001; ICH, 1996).

\section{MATERIALS AND METHODS}

\section{Raw material and reference standard}

Gramicidin - substance of reference (Sigma-Aldrich, potency $960 \mu \mathrm{g} / \mathrm{mg}$ ) and raw material (Alpharma).

\section{Reagents and solvents}

Sodium Chloride (Synth), dibasic potassium phosphate (Synth), monobasic potassium phosphate (Synth), ethyl alcohol (Synth), methanol (Merck), polysorbate 80 (Synth), meat extract (Prodimol), yeast extract (Prodimol), tryptone (Oxoid), glucose (CRQ), lactalbumin (Difco), casamine (Difco), and agar (Difco).

\section{Microorganisms and inoculums}

The cultures of Kocuria rhizophila ATCC 9341, Staphylococcus aureus ATCC 6538, Staphylococcus epidermidis ATCC 12228, and Enterococcus hirae ATCC 10541 were supplied by the Brazilian National Health and Quality Control (INCQS, RJ, Brazil), cultivated in antibiotic medium 1 and maintained in a refrigerator $\left(4 \pm 2{ }^{\circ} \mathrm{C}\right)$. Twenty-four hours before the assay, a new pealing was performed to obtain the inoculum at $1.0 \pm 0.1$ of absorbance, at $580 \mathrm{~nm}$ in a $0.9 \%$ sodium chloride solution. To select the test microorganism, 0.5 and $0.25 \mathrm{~mL}$ of this suspension were added to $100 \mathrm{~mL}$ of antibiotic medium 1 at $47 \pm 2{ }^{\circ} \mathrm{C}$, which was used as an inoculated layer. For the dosage of gramicidin, the surface layer consisted of inoculated nutrient agar with $K$. rhizophila (inoculum at $0.1 \%$ ).

\section{Culture media and solutions used}

Antibiotic medium 1 (Difco), nutrient agar (Prodimol - $5 \mathrm{~g}$ of gelatin peptone, $3 \mathrm{~g}$ of meat extract, $5 \mathrm{~g}$ of yeast extract, $5 \mathrm{~g}$ of glucose, $15 \mathrm{~g}$ of agar in $1000 \mathrm{~mL}$ of water), $7.0 \mathrm{pH}$ buffer (13.6 $\mathrm{g}$ of dibasic potassium phosphate and $4.0 \mathrm{~g}$ of monobasic potassium phosphate in $1000 \mathrm{~mL}$ of water) were used.

\section{Determination of assay conditions}

To determine the assay conditions, plates with two layers of antibiotic medium 1 were used: one non-inoculated $(21 \mathrm{~mL})$ and the other containing $4 \mathrm{~mL}$ of inoculated antibiotic medium 1 at $0.5 \%$ and $0.25 \%$, with the different microorganisms. Four stainless steel cylinders, measuring $8 \times 6 \times 10 \mathrm{~mm}$, were placed on the surface of the inoculated medium and filled with $200 \mu \mathrm{L}$ of the gramicidin solutions at $2.00,4.00,8.00$, and $16.0 \mu \mathrm{g} / \mathrm{mL}$ prepared in a $7.0 \mathrm{pH}$ buffer. The plates were left for 1 hour at room temperature and then incubated at $36.5^{\circ} \mathrm{C}$ for 18 hours. Different diluents were tested to prepare the gramicidin solutions, including ethyl alcohol at 95\%; acetone; $7.0 \mathrm{pH}$ buffer, containing polysorbate 80 at $0.1 \%$ and $1 \%$; and an aqueous solution of polysorbate 80 at $1 \%$. Other assays using the nutrient agar as 
a culture medium were also performed. Different ranges of gramicidin concentrations that lay within the 5.00 to $100 \mu \mathrm{g} /$ $\mathrm{mL}$ interval were also tested. The assessment of the assayed conditions was carried out by comparing the sharpness and the zone diameter of growth inhibition obtained.

\section{Dosage of gramicidin using nutrient agar}

Two layers of agar were used, with one noninoculated layer containing $21 \mathrm{~mL}$ of nutrient agar (base medium) and the other containing $4 \mathrm{~mL}$ of inoculated nutrient agar at $0.1 \%$. Six stainless steel cylinders, measuring $8 \times 6 \times 10 \mathrm{~mm}$, were placed on the surface of the inoculated medium. For the $3 \times 3$ design, three alternating cylinders were filled with $200 \mu \mathrm{L}$ of standard solutions (three concentrations), while the other three were filled with the sample solutions (three concentrations). Five assays were performed each using eight plates. For the $5 \times 1$ design, three cylinders were filled with $200 \mu \mathrm{L}$ of the reference solution (concentration of $11.3 \mu \mathrm{g} / \mathrm{mL}$ ), while the other three were filled with either the standard solution (concentrations of $5.00,7.50,16.9$, or $25.3 \mu \mathrm{g} / \mathrm{mL}$ ) or the sample solution $(11.3 \mu \mathrm{g} / \mathrm{mL})$. In each assay, three plates per concentration were prepared, except for that of the reference solution. Five assays were also performed. All plates were left for 1 hour at room temperature and then incubated at $36.5^{\circ} \mathrm{C}$ for 18 hours.

\section{Standard solution preparation}

Exactly $25 \mathrm{mg}$ of reference standard gramicidin was weighed and transferred to a volumetric flask of 25 $\mathrm{mL}$ and dissolved in ethyl alcohol at 95\% (concentration of $1000 \mu \mathrm{g} / \mathrm{mL}$ ). Aliquots of the solution were diluted in polysorbate 80 at $1 \%$ to obtain the concentrations of 5.00, $7.50,11.3,16.9$, and $25.3 \mu \mathrm{g} / \mathrm{mL}$ used in the $5 \times 1$ design, whereas $5.00,10.0$, and $20.0 \mu \mathrm{g} / \mathrm{mL}$ were used in the $3 \times 3$ design.

\section{Sample preparation}

The raw material sample was prepared by the same procedure used for the reference standard.

\section{Method validation}

The method was validated by determining the parameters of calibration curve, precision, accuracy, robustness, selectivity, and detection and quantification limits (Hubert et al., 2007a,b; Rozet et al., 2007a; Brasil, 2003; FDA, 2001; ICH, 1996).

\section{Calibration curve}

The calibration curve was obtained using five reference standard concentrations $(5.00,7.50,11.3,16.9$, and $25.3 \mu \mathrm{g} / \mathrm{mL}$ ), whose assays were performed on four different days.

\section{Precision}

Precision of the method was determined by repeatability (intra-assay) and intermediate precision (interassay). Repeatability was assessed, in triplicate, through the assay of solutions at concentrations of $2.50,5.00$, and $10.0 \mu \mathrm{g} / \mathrm{mL}(50 \%) ; 5.00,10.0$, and $20.0 \mu \mathrm{g} / \mathrm{mL}(100 \%)$; and $7.50,15.0$, and $30.0 \mu \mathrm{g} / \mathrm{mL}(150 \%)$ for the $3 \times 3$ design and in quintuplicate of solutions at concentrations of 5.00, 11.3 , and $25.3 \mu \mathrm{g} / \mathrm{mL}$ for the $5 \times 1$ design, all on the same day. Intermediate precision was verified by evaluating the results on two different days.

\section{Accuracy}

Accuracy was determined by means of microbiological assay, in quintuplicate, of the reference standard solutions at concentrations of $5.00,11.3$, and $25.3 \mu \mathrm{g} / \mathrm{mL}$ for the $5 \times 1$ design. For the $3 \times 3$ design, reference standard solutions at concentrations of $2.50,5.00$, and $10.0 \mu \mathrm{g} / \mathrm{mL}$ (50\%); 5.00, 10.0, and $20.0 \mu \mathrm{g} / \mathrm{mL}(100 \%)$; and 7.50, 15.0, and $30.0 \mu \mathrm{g} / \mathrm{mL}(150 \%)$ were assayed in triplicate. The assays were performed on two different days.

\section{Selectivity}

To prove that the microbiological assay was selective, the analyte was submitted to the hydrolysis conditions described by Ishii and Witkop (1964). The degradation product was assayed using the high performance liquid chromatography (HPLC) method to test for the composition specified in British Pharmacopoeia (2007) and by the microbiological method using the two designs $(3 \times 3$ and $5 \times 1)$. The HPLC analyses were carried out on an Agilent 1200 system, using a C-18 reversed-phase colu$\mathrm{mn}(250 \times 4.6 \mathrm{~mm}$ i.d. and $5 \mu \mathrm{m}$ particle size $)$, a flow rate of $1.0 \mathrm{ml} / \mathrm{min}$, a mixture of methanol and water (29:71) as mobile phase, and detection wavelength of $282 \mathrm{~nm}$. The run time was 2.5 times $(90 \mathrm{~min})$ the retention time of gramicidin A1 (about 36 min) (British Pharmacopeia, 2007). For the microbiological assay, degradation product solutions at concentrations of $5.00,10.0$, and $20.0 \mu \mathrm{g} / \mathrm{mL}$ $(3 \times 3)$ and $11.3 \mu \mathrm{g} / \mathrm{mL}(5 \times 1)$ were prepared in polysorbate 80 at $1 \%$, assayed in comparison with the diluent and the reference standard solutions $(5.00,10.0$, and $20.0 \mu \mathrm{g} / \mathrm{mL}$ for $3 \times 3$ and $5.00,7.50,11.3,16.9$, and $25.3 \mu \mathrm{g} / \mathrm{mL}$ for $5 \mathrm{x} 1$ ). 


\section{Limits of Detection and Quantification}

To determine the detection and lower quantification limits, reference standard solutions at concentrations 1.00 , $2.00,3.00$, and $4.00 \mu \mathrm{g} / \mathrm{mL}$ and the diluent were assayed by the $5 \times 1$ design. The upper quantification limit was determined using the $5 \times 1$ design with reference standard solutions at concentrations of $28.0,30.0$, and $32.0 \mu \mathrm{g} / \mathrm{mL}$. The assays were carried out on two different days.

\section{Robustness}

To evaluate robustness, reference standard solutions at concentrations $5.00,7.50,11.3,16.9$, and $25.3 \mu \mathrm{g} / \mathrm{mL}$ were assayed in nutrient agar with a $\mathrm{pH}$ adjusted to 6 and 8 , and on plates with a base layer consisting of either antibiotic medium 1 or a culture medium of the same composition as nutrient agar substituting the gelatin peptone for tryptone, casamine, or lactalbumin.

\section{Statistical analysis}

The analysis of variance (ANOVA) was used to compare the results obtained under the different conditions tested, such as the selection of the test microorganism, concentration of the inoculum, use of different diluents, and different concentration of gramicidin, to determine the detection and quantification limits. The Bonferroni test was used as a test of averages.

The calibration curves constructed were assessed through residue analysis (homoscedasticity, normality, and independence of residues) and linear regression analysis using the ordinal least squares method (Souza, Junqueira, 2005; Finney, 1978). The analysis of covariance (ANCOVA) was used to compare the calibration curves obtained on different days to assess linearity as well as under the different conditions tested for the robustness parameter (Snedecor, Cochran, 1996).

To calculate the potency of the raw material gramicidin by the $3 \times 3$ design, the Hewitt equation was used (Hewitt, 2004). The assay was tested statistically using the parallel linear model, residue analysis, and linear regression analysis. The ANOVA test was used to verify the validity of the assay (Souza, Junqueira, 2005; Finney, 1978).

For the $5 \times 1$ design, the equation below was applied to correct the growth inhibition:

$$
\overline{\mathrm{y}}_{\mathrm{Pcj}}=\overline{\mathrm{y}}_{\mathrm{Pj}}+\left(\overline{\overline{\mathrm{y}}}_{\mathrm{P} 3}-\overline{\mathrm{y}}_{\mathrm{P} 3 \mathrm{j}}\right)
$$

in which $\bar{y}_{\mathrm{Pcj}}$ is the corrected average of the zone diameter of growth inhibition corresponding to the concentration present on the $\mathrm{j}$ plate; $\overline{\mathrm{y}}_{\mathrm{Pj}}$ is the average of the zone diameter of growth inhibition corresponding to the concentration present on the $\mathrm{j}$ plate; $\overline{\overline{\mathrm{y}}}_{\mathrm{P} 3}$ is the average of all the averages of the zone diameter of growth inhibition corresponding to the concentration of $11.3 \mu \mathrm{g} / \mathrm{mL} ; \bar{y}_{\mathrm{P} 3 \mathrm{j}}$ is the average of the zone diameter of growth inhibition corresponding to the concentration of $11.3 \mu \mathrm{g} / \mathrm{mL}$ present on the $\mathrm{j}$ plate. Three corrected averages of the zone diameter of growth inhibition were obtained for each concentration, not including the reference concentration $(11.3 \mu \mathrm{g} / \mathrm{mL})$, which was used for the correction. To calculate the potency of the raw material gramicidin, the Hewitt equation was used (Hewitt, 2004). The assay was analyzed statistically using residue analysis and linear regression analysis (Souza, Junqueira, 2005; Finney, 1978). The significance level for all the analyses was $\alpha=0.05$.

\section{RESULTS AND DISCUSSION}

K. rhizophila ATCC 9341 was the strain chosen as the test microorganism because it produced a larger and clearer zone diameter of growth inhibition than the other tested microorganisms: $S$. aureus ATCC 6538, E. hirae ATCC 10541 and S. epidermidis ATCC 12228.

Gramicidin has poor water solubility and low diffusibility, aspects which stem from its chemical structure. It contains the terminal $\mathrm{N}$ and $\mathrm{C}$ groups, linked to the formyl and ethanolamine groups, respectively. Hence, gramicidin is uncharged at all $\mathrm{pH}$ values, which explains its low solubility in water (Koo et al., 2001). In addition, it possesses a high molecular weight. These properties justify the low diffusibility of the molecule in solid culture medium, thus generating small zones of growth inhibition (Viola, Canestrini, 1966).

Many conditions were tested with the objective of obtaining larger zones, such as different diluents for the preparation of solutions, culture media, and the concentration of the inoculum. More optimal results were obtained when the nutrient agar was used as the culture medium and an aqueous solution of polysorbate 80 at $1 \%$ was used as the diluent, preparing the gramicidin solutions within the range 5.00 to $25.3 \mu \mathrm{g} / \mathrm{mL}$ and the inoculum at $0.1 \%$ of $K$. rhizophila. Within this concentration interval, the regression between the logarithm of the concentration and the zone diameter of growth inhibition was considered significant. The linear model proved to be adequate as it could be proven that the residues followed a normal distribution pattern and were independent, i.e. homoscedasticity was observed and lack of fit was not significant. The calibration curve was obtained through the $5 \times 1$ experimental design; therefore, the mean of the corrected averages of zone diameter of growth inhibition $(\mathrm{mm})$ for the reference standard solutions was: 10.60 (R.S.D. $1.85 \%$ ) for the concentration of $5.00 \mu \mathrm{g} / \mathrm{mL}$; 
11.18 (R.S.D. $0.54 \%$ ) for $7.50 \mu \mathrm{g} / \mathrm{mL} ; 11.75$ (R.S.D. $1.13 \%$ ) for $11.3 \mu \mathrm{g} / \mathrm{mL}$; 12.35 (R.S.D. $1.05 \%$ ) for $16.9 \mu \mathrm{g} / \mathrm{mL}$, and 13.07 (R.S.D. $0.29 \%$ ) for $25.3 \mu \mathrm{g} / \mathrm{mL}$. Five calibration curves were constructed (Table I), two on the same day and the remainder on different days. All presented a coefficient of correlation (r) greater than 0.98 (Brasil, 2003; FDA, 2001) and when compared, no significant difference was found between the intercepts and slopes.

TABLE I - Parameters of calibration curve (intercept $-\mathrm{a}$, slope $\mathrm{b}$, coefficient of correlation $-r$, and coefficient of determination $-r^{2}$ ) for gramicidin within the range 5.00 to $25.3 \mu \mathrm{g} / \mathrm{mL}$

\begin{tabular}{lcccc}
\hline Lines & $\boldsymbol{a} \pm$ SD & $\boldsymbol{b} \pm$ SD & $\boldsymbol{r}$ & $\boldsymbol{r}^{2}$ \\
\hline Day 1 $\mathrm{A}^{\text {a }}$ & $8.00 \pm 0.10$ & $3.59 \pm 0.09$ & 0.997 & 0.994 \\
Day 1 B & $8.00 \pm 0.22$ & $3.55 \pm 0.21$ & 0.984 & 0.967 \\
Day 2 & $7.74 \pm 0.24$ & $3.81 \pm 0.21$ & 0.985 & 0.969 \\
Day 3 & $7.83 \pm 0.16$ & $3.60 \pm 0.14$ & 0.991 & 0.983 \\
Day 4 & $8.26 \pm 0.24$ & $3.35 \pm 0.22$ & 0.98 & 0.956 \\
\hline
\end{tabular}

${ }^{a}$ Lines 1A and 1B were obtained on the same day, while 2, 3, and 4 were obtained on different days.

The $3 \times 3$ design assay proved to be valid for the concentrations $5.00,10.0$, and $20.0 \mu \mathrm{g} / \mathrm{mL}$, inserted within the linear range 5.00 to $25.3 \mu \mathrm{g} / \mathrm{mL}$. No deviation of parallelism or significant curvatures was observed. In addition, the residue analysis for both the standard's and sample's curves demonstrated that the linear model was appropriate for both.

The repeatability (intra-assay) and intermediate precision (inter-assays) were expressed as the relative standard deviation of a series of measures. The results are shown in Table II. The relative deviations were well below
$15 \%$ for all levels of concentrations tested, thus indicating appropriate intra- and inter-assay precision (Brasil, 2003; FDA, 2001).

According to the trueness parameter, there was no evidence indicating systematic errors in either experimental design (Hubert et al., 2007a; Rozet et al., 2007a; INMETRO, 2003). Upon plotting the potencies determined experimentally $v s$. the theoretical value, a line was obtained. The experimental values were approximate to the true values, thus the line did not shift away from the ideal line, in which the intercept was equal to zero and the slope was equal to one, in turn proving the absence of systemic errors (Rozet et al., 2007a; INMETRO, 2003).

The method had appropriate accuracy, as can be seen by the values calculated for the $\beta$ tolerance interval (Figure 1) for each concentration level, which showed a maximum variation of $15 \%$ for both designs (Hubert et al., 2007a, b; Rozet et al., 2007a; FDA, 2001). Accuracy is represented by the combination of the random (precision) and systematic (trueness) errors, which were considered in the $\beta$ tolerance interval calculation. This represents the interval in which $\beta \%$ of the future individual results is expected (Rozet et al., 2007b).

The method proved to be selective for gramicidin as the degradation product assayed by the microbiological method showed only local activity at the tested concentrations, with no significant difference between the zone diameter of growth inhibition of the different concentrations and that of the diluent. In addition, the degradation of gramicidin was proven by the absence of the characteristic peaks of the antibiotic within the chromatogram of the degradation product (Figure 2).

To determine the limit of detection, upon comparing the zone diameter of growth inhibition of the different con-

TABLE II - Results of potency of solutions of different concentrations of gramicidin determined by agar diffusion method to study precision and accuracy

\begin{tabular}{|c|c|c|c|c|c|c|}
\hline \multirow{2}{*}{ Replicates } & \multicolumn{3}{|c|}{$5 \times 1$ Design } & \multicolumn{3}{|c|}{$3 \times 3$ Design } \\
\hline & $5.00 \mu \mathrm{g} / \mathrm{mL}$ & $11.3 \mu \mathrm{g} / \mathrm{mL}$ & $25.3 \mu \mathrm{g} / \mathrm{mL}$ & $50 \%$ & $100 \%$ & $150 \%$ \\
\hline 1 & 5.37 & 11.10 & 25.26 & & & \\
\hline 2 & 5.30 & 11.59 & 25.13 & 51.99 & 101.40 & 152.05 \\
\hline 3 & 5.21 & 11.33 & 24.93 & 50.12 & 101.76 & 148.03 \\
\hline 4 & 5.17 & 11.09 & 25.02 & 48.30 & 102.97 & 149.76 \\
\hline 5 & 4.97 & 11.40 & 25.11 & & & \\
\hline 1 & 5.25 & 11.75 & 25.71 & & & \\
\hline 2 & 4.96 & 11.34 & 25.98 & 47.68 & 102.72 & 159.75 \\
\hline 3 & 5.25 & 10.96 & 25.09 & 52.64 & 99.44 & 147.16 \\
\hline 4 & 5.42 & 11.71 & 25.54 & 50.38 & 100.30 & 148.36 \\
\hline 5 & 5.11 & 10.94 & 25.35 & & & \\
\hline Intra-assay average & 2.96 & 1.90 & 0.49 & 3.68 & 0.81 & 1.34 \\
\hline Inter-assay RSD & 2.94 & 2.64 & 1.33 & 3.90 & 1.35 & 3.10 \\
\hline
\end{tabular}


$3 \times 3$

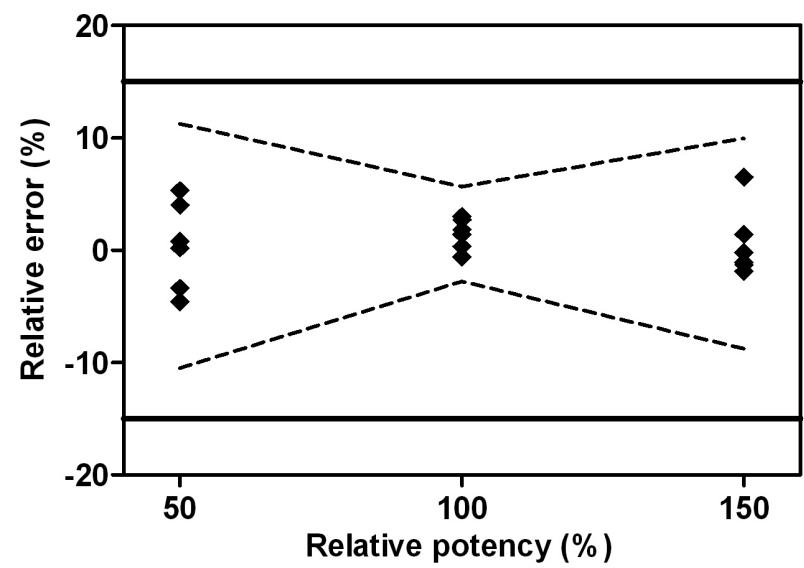

$5 \times 1$

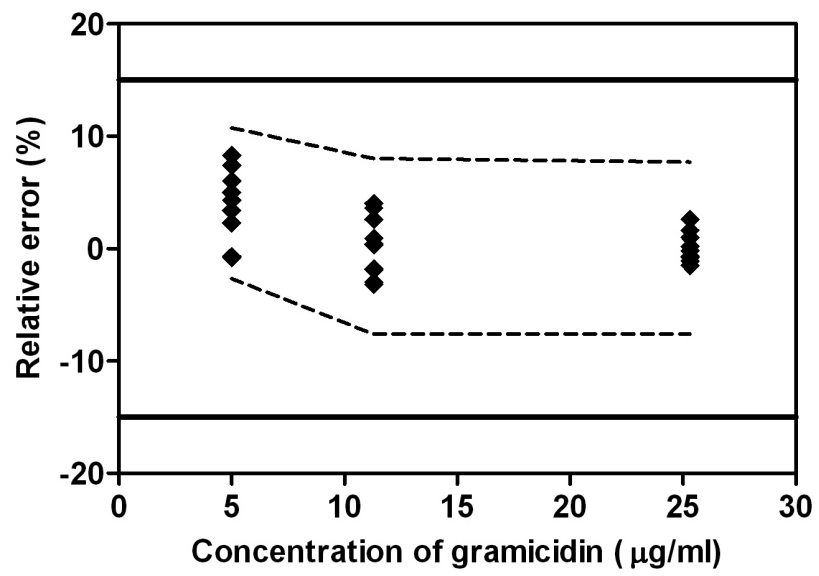

FIGURE 1 - Accuracy profile obtained for method of microbiological dosage of gramicidin using 3x3 and 5x1 designs. Dashed lines represent acceptance limits $(-15 \%, 15 \%)$, whereas dotted lines represent $95 \%$ tolerance interval reached. When tolerance intervals are included in acceptance limits, the assay can be quantified accurately.

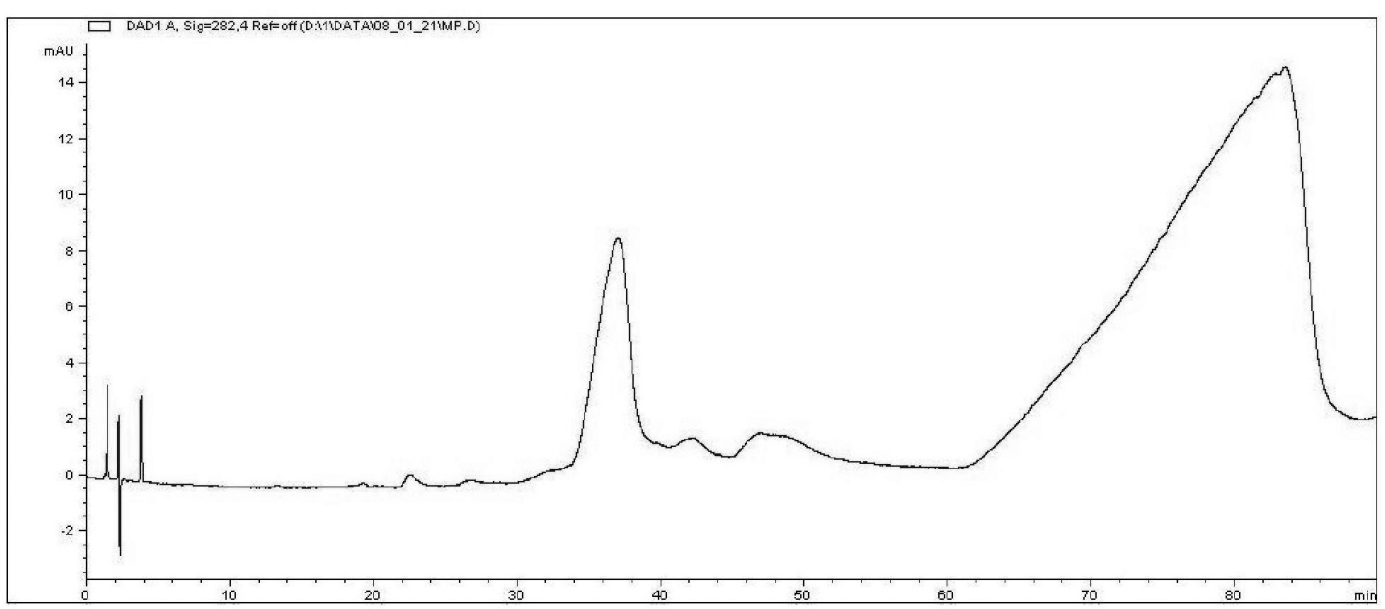

(A)

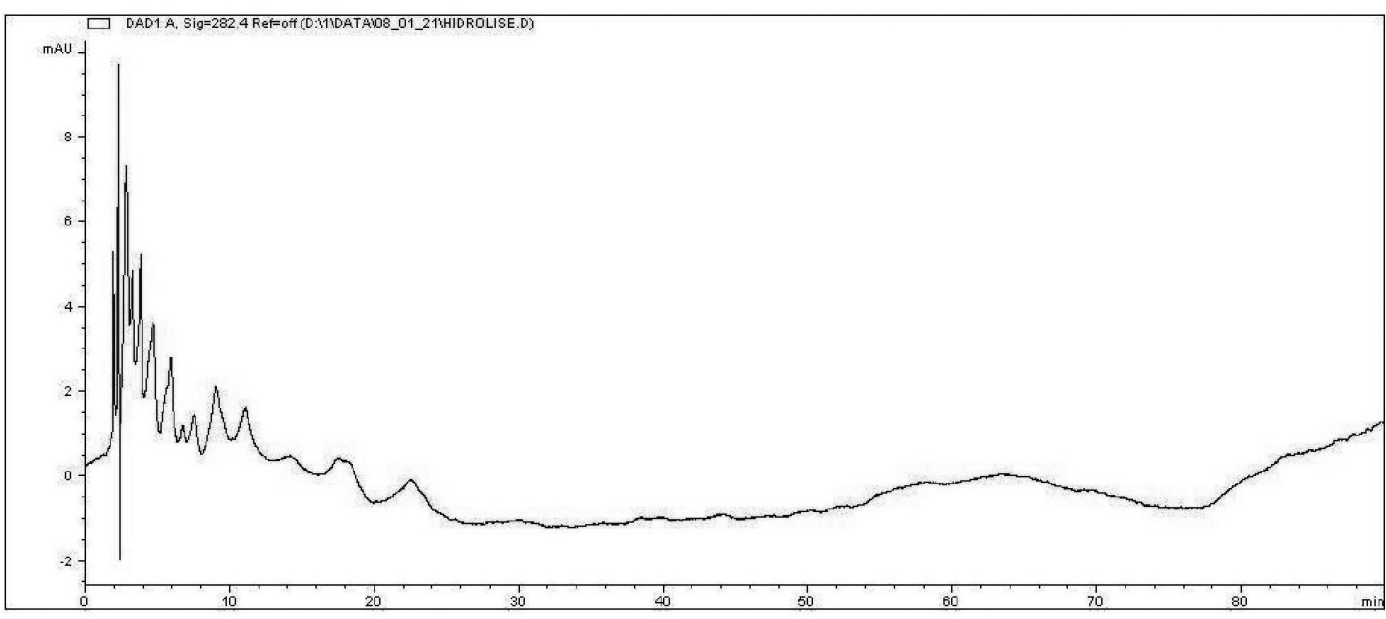

(B)

FIGURE 2 - Chromatogram obtained through analysis of raw material (A) and degradation product (B) of gramicidin using HPLC method. 
centrations of gramicidin $(1.00,2.00,3.00$ e $4.00 \mu \mathrm{g} / \mathrm{mL})$ and of the diluent, a significant difference was found between them. It was shown that the lowest concentration to produce a zone diameter of growth inhibition different to that of the diluent was $2.00 \mu \mathrm{g} / \mathrm{mL}$. This value was thus considered the limit of detection. The results for the potency of the concentrations $2.00,3.00,4.00,28.0,30.0$, and $32.0 \mu \mathrm{g} / \mathrm{mL}$ were neither precise nor accurate. Nevertheless, satisfactory results were obtained when using the concentrations 5.00 and $25.3 \mu \mathrm{g} / \mathrm{mL}$ (Table II), determined as the upper and lower quantification limits, respectively.

A parallelism between the lines obtained when using the nutrient agar with a $\mathrm{pH}$ of 6,7 , and 8 was evident. However, a reduction in the zone diameter of growth inhibition was seen within the $\mathrm{pH}$ conditions of 6 and 8 . A similar result was obtained when antibiotic medium 1 was used as a base layer. Upon using other media as base layers, no growth of the test microorganism was observed. Therefore, the $\mathrm{pH}$ conditions and composition of the medium should be controlled.

The experimental values for the potency of gramicidin in the sample are given in Table III. The combined potency for the $3 \times 3$ design was $105.37 \%$, whereas for the $5 \times 1$ design was $105.22 \%$, with an estimated confidence interval at $95 \%$ ranging from $102.34 \%$ to $108.49 \%$ and $102.27 \%$ to $108.25 \%$, respectively. Such results are within pharmacopoeic specifications for the potency limit $(900 \mu \mathrm{g} / \mathrm{mg})$ and confidence limit $( \pm 5 \%)$, thus proving that the method produced appropriate and precise results (British Pharmacopoeia, 2007).

TABLE III - Potency data obtained in analysis of raw material gramicidin using microbiological assay of diffusion on plates

\begin{tabular}{ccc}
\hline Replicates & \multicolumn{2}{c}{ Potency } \\
\cline { 2 - 3 } & 3x3 Design & 5x1 Design \\
\hline 1 & $106.99 \%$ & $105.89 \%$ \\
2 & $106.50 \%$ & $105.03 \%$ \\
3 & $105.68 \%$ & $105.29 \%$ \\
4 & $104.43 \%$ & $106.53 \%$ \\
5 & $103.83 \%$ & $103.10 \%$ \\
\hline
\end{tabular}

The precision of the designs was compared, and no significant difference was found.

\section{CONCLUSION}

These results indicated that the microbiological assay of the cylinder-plate method offered good precision, accuracy, selectivity, as well as an appropriate calibration curve in the concentration range of 5.00 to $25.3 \mu \mathrm{g} / \mathrm{mL}$.
Therefore, this method can be used to quantify the activity of the raw material gramicidin.

\section{ACKNOWLEDGEMENTS}

The authors wish to thank CNPq for their financial support and Kinder for its kind donations of raw materials.

\section{REFERENCES}

BOSSCHA, M., DISSEL, J., KUIJPER, E., SWART, W., JAGER, M., The efficacy and safety of topical polymyxin $\mathrm{B}$, neomycin and gramicidin for treatment of presumed bacterial corneal ulceration. Br. J. Ophthalmol., v.88, n.1, p.25-28, 2004.

BRASIL. Resolução RE n 899 de 29 de Maio de 2003. Guia para validação de métodos analíticos e bioanalíticos. ANVISA. Diário Oficial da União. Poder Executivo, Brasília DF, 02 de Junho de 2003. Available at: <www.anvisa.gov.br>. Accessed on: 11 nov. 2009.

BRITISH pharmacopoeia. London: Her Majesty's Stationery Office, 2007. CD-ROM.

FOOD AND DRUG ADMINISTRATION. Guidance for Industry, Bioanalytical Methods Validation, 2001. Available at: <www.fda.gov>. Accessed on: 11 nov. 2009.

FINNEY, D. J. Statistical method in biological assay. 3.ed. London: Charles Griffin \& Co. Ltd., 1978. 508 p.

HEWITT, W. Microbiological assay for pharmaceutical analysis: a rational approach. 1.ed. New York:INTERPHARM,2007.260p.

HUBERT, P.; NGUYEN-HUU, J.; BOULANGER, B.; CHAPUZET, E.; CHIAP, P.; COHEN, N.; COMPAGNON, P.; DEW'E, W.; FEINBERG, M.; LALLIER, M.; LAURENTIE, M.; MERCIER, N.; MUZARDI, G.; NIVET, C.; VALAT, L.; ROZET, E. Harmonization of strategies for the validation of quantitative analytical procedures A SFSTP proposal - Part II. J. Pharm. Biom. Anal., v.45, n.1, p.70-81, 2007a.

HUBERT, P.; NGUYEN-HUU, J.; BOULANGER, B.; CHAPUZET, E.; COHEN, N.; COMPAGNON, P.; DEW'E, W; FEINBERG, M.; LAURENTIE, M.; MERCIER, N.; MUZARD, G.; VALAT, L.; ROZET, E. Harmonization of strategies for the validation of quantitative analytical procedures A SFSTP proposal-Part III. J. Pharm. Biom. Anal., v.45, n.1, p.82-96, 2007b. 
INTERNATIONAL CONFERENCE ON HARMONISATION.

ICH. Topic Q2B Validation of analytical procedures: methodology. Geneva: ICH Secretariat, 1996. 9 p.

ISHII, S.; WITKOP, B. Gramicidin A. II. Preparation and Properties of "seco-Gramicidin A. J. Am. Chem. Soc., v.86, n.9, p.1848-1853, 1964.

KOO, S.; BAYER, A.; YEAMEN, M. Diversity in antistaphylococcal mechanisms among membrane-targeting antimicrobial peptides. Infect. Imun., v.69, n.8, p.49164922, 2001.

ROZET, E.; CECCATP, A.; HUBERT, C.; ZIEMONS, E.; OPREAN, R.; RUDAZ, S.; BOULANGER, B.; HUBER, P. Analysis of recent pharmaceutical regulatory documents on analytical method validation. J. Chromatogr. A, v.1158, n.1-2, p.111-125, 2007a.

Rozet, E., Hubert, C., CECCATO, A., DeWÉ, W., ZIEMONS, E., MOONEN, F., MICHAIL, K., WINTERSTEIGER, R., STREEL, B., BOULANGER, B., HUBERT, B. Using tolerance intervals in pre-study validation of analytical methods to predict in-study results. The fit-for-future-purpose concept. J. Chromatogr. A, v.1158, n.1-2, p.126-137, $2007 \mathrm{~b}$.
SNEDECOR, G.W.; COCHRAN, W.G. Statistical methods. 8.ed. Ames: Jowa State University, 1996. 503 p.

SOUZA, S.V.C.; JUNQUEIRA, R.G. A procedure to assess linearity by ordinary least squares method. Anal. Chim. Acta, v.552, n.1-2, p.25-35, 2005.

UNITED STATES PHARMACOPOEIA. 31.ed. Rockville: The United States Pharmacopeial Convention, 2008. p.103-109.

VIOLA, M.R.; CANESTRINI, C. Sulla determinazione microbiologica della tirotricina. Boll. Chim. Farm., v.105, n.9, p.688-694, 1966.

VUILLEUMIER, M.; ANKER, L. Mikrobiologische wertbestimmung von antibiotika in der Pharmacopoea Helvetica. Pharm. Acta Helv., v.33, n.2, p.621-633, 1958.

ZAIAS, N.; McCORMICK, G.; DILORENZO, P.; KANOF, N.; SCHOCH, E.; SCHNEIDERMAN, N. Topical combination therapy for cutaneous candidiasis: a double-blind trial. Curr. Ther. Res. Clin. Exper., v.29, n.3, p.463-476, 1981.

Received for publication on $19^{\text {th }}$ October 2010 Accepted for publication on $20^{\text {th }}$ May 2011 